\title{
WELL-BEING OVER TIME IN BRITAIN AND THE USA
}

\author{
David G. Blanchflower \\ Andrew J. Oswald \\ Working Paper 7487 \\ http://www.nber.org/papers/w7487 \\ NATIONAL BUREAU OF ECONOMIC RESEARCH \\ 1050 Massachusetts Avenue \\ Cambridge, MA 02138 \\ January 2000
}

For their helpful ideas, we are grateful to Michael Argyle, Steve Broadberry, Andrew Clark, Mike Clements, Ed Diener, Rafael Di Tella, Richard Freeman, Jay Hull, Bob Kleck, Robert MacCulloch, Avner Offer, Jeff Round, Jonathan Skinner, Ian Walker, Peter Warr (who was a member of an earlier joint research project), Chris Willmore, and Justin Wolfers. The views expressed herein are those of the authors and not necessarily those of the National Bureau of Economic Research.

(C) 2000 by David G. Blanchflower and Andrew J. Oswald. All rights reserved. Short sections of text, not to exceed two paragraphs, may be quoted without explicit permission provided that full credit, including $\mathbb{C}$ notice, is given to the source. 
Well-Being Over Time in Britain and the USA David G. Blanchflower and Andrew J. Oswald NBER Working Paper No. 7487

January 2000

JEL No. J2

\section{ABSTRACT}

The standard of living in the industrialized nations has been steadily increasing over the last few decades. Yet some observers wonder whether we are really getting any happier. This paper addresses that question by examining well-being data on 100,000 randomly sampled Americans and Britons from the early 1970s to the late 1990s. Reported levels of happiness have declined over the period in the United States. Life satisfaction has been approximately flat through time in Great Britain. Counter to the general US trend, the happiness of blacks in that nation has risen since the early 1970s. The black-white happiness differential has diminished. The happiness of American men has grown. Despite legislation aimed to reduce gender discrimination, the well-being of women has fallen noticeably. Well-being equations have a stable structure: the British equations look almost identical to the US ones. Money does buy happiness. The paper also calculates the dollar values of life events like unemployment and divorce. They are large. A lasting marriage, for example, is calculated to be worth $\$ 100,000$ a year.

David Blanchflower

Department of Economics

6106 Rockefeller Hall

Dartmouth College

Hanover, NH 03755-3514

and NBER

david.g.blanchflower@dartmouth.edu
Andrew J. Oswald

Department of Economics

Warwick University

Coventry CV4 7AL

UK

andrew.oswald@warwick.ac.uk 


\title{
Well-Being Over Time in Britain and the USA
}

\author{
David G. Blanchflower and Andrew J. Oswald
}

"We hold these truths to be self-evident, that all men are created equal, that they are endowed by their Creator with certain unalienable rights, that among these are life, liberty and the pursuit of happiness." U.S. Declaration of Independence, July 4, 1776.

\section{Introduction}

One thing that unites different kinds of social scientists is a concern to understand the forces that affect people's well-being. What makes individuals happy? What leads to happy societies? These are difficult questions, but they seem important.

This paper studies the numbers that people report when asked questions about how happy they feel and how satisfied with life. There are, transparently, limitations to such statistics, and an inquiry of this sort suffers the disadvantage that controlled experiments are out of reach. But it seems unlikely that human happiness can be understood without, in part, listening to what human beings say.

Sources of information exist that have for many years recorded individuals' survey responses to questions about well-being. These responses have been studied intensively by psychologists ${ }^{1}$, examined a little by sociologists and political scientists ${ }^{2}$, and largely ignored by economists ${ }^{3}$. Some economists may defend this neglect. They will emphasize the unreliability of subjective data - perhaps because they are unaware of the large literature by research psychologists that uses such numbers, or perhaps because they believe economists are better judges of human motivation than those researchers.

1 Earlier work includes Andrews (1991), Argyle (1989), Campbell (1981), Diener (1984), Diener et al (1999), Douthitt et al (1992), Fox and Kahneman (1992), Larsen et al (1984), Mullis (1992), Shin (1980), Veenhoven (1991, 1993), and Warr (1990).

2 For example, Inglehart (1990) and Gallie et al (1998). There is also a related empirical literature on interactions between economic forces and people's voting behavior; see for example Frey and Schneider (1978).

3 The recent research papers of Andrew Clark, Bruno Frey and Yew Kwang Ng are exceptions (Clark, 1996; Clark and Oswald, 1994; Frey and Stutzer, 1998, 1999; Ng, 1996, 1997). See also Frank (1985, 1997), Blanchflower and Freeman (1997), Blanchflower and Oswald (1998, 1999), Blanchflower, Oswald and Warr (1993), MacCulloch (1996), and Di Tella et al (1999). Offer (1998) contains interesting ideas about the post-war period and possible reasons for a lack of rising well-being in industrialized society. 
Most economists, however, are probably unaware that data of this sort are available, and have not thought of whether empirical measures approximating the theoretical construct 'utility' might be useful in their discipline.

\section{On Happiness and Measurement}

One definition of happiness is the degree to which an individual judges the overall quality of his or her life as favorable (Veenhoven 1991, 1993). Psychologists draw a distinction between the wellbeing from life as a whole and the well-being associated with a single area of life: these they term "context-free" and "context-specific". These researchers view it as natural that a concept such as happiness should be studied in part by asking people how they feel.

One issue in the psychology literature has been whether a well-being measure is, in their

terminology, reliable and valid. Self-reported measures are recognized to be a reflection of at least four factors: circumstances, aspirations, comparisons with others, and a person's baseline happiness or dispositional outlook (e.g. Warr 1980, Chen and Spector, 1991)). Konow and Earley (1999) describes evidence that recorded happiness levels have been demonstrated to be correlated with:

1. Objective characteristics such as unemployment.

2. The person's recall of positive versus negative life-events.

3. Assessments of the person's happiness by friends and family members.

4. Assessments of the person's happiness by his or her spouse.

5. Duration of authentic or so-called Duchenne smiles (a Duchenne smile occurs when both the zygomatic major and obicularus orus facial muscles fire, and human beings identify these as 'genuine' smiles).

6. Heart rate and blood-pressure measures responses to stress.

7. Skin-resistance measures of response to stress 
8. Electroencephelogram measures of prefrontal brain activity.

Rather than summarize the psychological literature's assessment of well-being data, this paper refers readers to the checks on self-reported happiness statistics that are discussed in Argyle (1989) and Myers (1993), and to psychologists' articles on reliability and validity, such as Fordyce (1985), Larsen, Diener, and Emmons (1984), Pavot and Diener (1993), and Watson and Clark (1991).

The idea used in the paper is that there exists a reported well-being function

$$
\mathrm{r}=\mathrm{h}(\mathrm{u}(\mathrm{y}, \mathrm{z}, \mathrm{t}))+\mathrm{e}
$$

where $\mathrm{r}$ is some self-reported number or level (perhaps the integer 4 on a satisfaction scale, or "very happy" on an ordinal happiness scale), $\mathrm{u}(\ldots)$ is to be thought of as the person's true well-being or utility, $\mathrm{h}($.$) is a continuous non-differentiable function relating actual to reported well-being, \mathrm{y}$ is real income, $\mathrm{z}$ is a set of demographic and personal characteristics, $\mathrm{t}$ is the time period, and $\mathrm{e}$ is an error term. As plotted in Figure 1, the function $\mathrm{h}($.$) rises in steps as u increases. It is assumed, as seems$ plausible, that $\mathrm{u}(\ldots)$ is a function that is observable only to the individual. Its structure cannot be conveyed unambiguously to the interviewer or any other individual. The error term, e, then subsumes among other factors the inability of human beings to communicate accurately their happiness level (your 'two' may be my 'three' $)^{4}$. The measurement error in reported well-being data would be less easily handled if well-being were to be used as an independent variable.

This approach may be viewed as an empirical cousin of the experienced-utility idea advocated by Kahneman et al (1997). The structure of equation 1 makes it suitable for estimation as an ordered

\footnotetext{
4 It may be worth remarking that this approach recognises the social scientist's instinctive distrust of a single person's subjective 'utility'. An analogy might be to a time before human beings had accurate ways of measuring people's height. Selfreported heights would contain information but be subject to large error. They would predominantly be useful as ordinal data, and would be more valuable when averaged across people than used as individual observations.
} 
probit or logit. In this way, 'true' utility is the latent variable, and the subjectivity of responses can be thought of as being swept into the error term.

It is possible to view some of the self-reported well-being questions in the psychology literature as assessments of a person's lifetime or expected stock value of future utilities. Equation 1 would then be rewritten as an integral over the $\mathrm{u}(\ldots)$ terms. This paper, however, will use a happiness question that seems more naturally interpreted as a flow rather than a stock.

In what has since emerged as seminal research, Easterlin (1974, and more recently 1995) was one of the first social scientists to study data over time on the reported level of happiness in the United States. One of his aims was to argue that individual well-being is the same across poor countries and rich countries. The author suggests that we should think of people as getting utility from a comparison of themselves with others close to them: happiness is relative. Hirsch (1976), Scitovsky (1976), Layard (1980), Frank (1985, 1999) and Schor (1998) have argued a similar thesis; a different tradition, with equivalent implications, begins with Cooper and Garcia-Penalosa (1999) and Keely (1999).

On the trend in well-being over time, Easterlin's paper concludes: "... in the one time-series studied, that for the United States since 1946, higher income was not systematically accompanied by greater happiness" (p.118). This result has become well-known. Oswald (1997) makes the point that Richard Easterlin's data may not actually support it; his longest consistent set of happiness levels seems to find that Americans were becoming happier (39\% very happy in 1946 to 53\% very happy in 1957). But, as Easterlin shows, splicing together surveys with slightly different well-being questions over a longer set of years does suggest a flat trend in well-being in the early post-war period.

This paper begins by examining information from the General Social Surveys of the United States. Although little used by economists, these have for many years been interviewing people about their levels of happiness. GSS data are available in most of the years from 1972 to 1998 . The size of 
sample averages approximately fifteen hundred individuals per annum. Different people are interviewed each year: the GSS is not a panel.

Are Americans getting happier over time? In the early 1970s, 34\% of those interviewed in the General Social Survey described themselves as 'very happy'. By the late 1990s, the figure was 30\%. For women, the numbers go from $36 \%$ at the start of the period, to $29 \%$ a quarter of a century later. The raw patterns are in Table 1. The question asked is:

Taken all together, how would you say things are these days -- would you say that you are very happy, pretty happy, or not too happy? (GSS Question 157)

The same wording has been used for the last twenty six years. It is clear from the table that there is a reasonable amount of stability in the proportion of people giving different well-being scores, and that, not unexpectedly, the bulk of survey respondents place themselves in the middle category ('pretty happy') of those offered.

To explore the issue more carefully, it is natural to look at a regression-adjusted time trend. Table 2A estimates regression equations in which the dependent variable is reported happiness. These ordered logit equations control only for exogenous demographic characteristics: age, age squared, gender, and race.

Table 2A contains a number of findings that might have been hard to predict. Column 1 of the table shows that America is apparently becoming systematically less happy (in the eyes of Americans themselves). There is a negative time trend, -0.0027 , with a t-statistic sufficiently large to allow the null hypothesis of zero to be rejected. Men report lower happiness scores than women, although the size of the difference between males and females appears to be small. Blacks and other non-white races are 
less happy than whites. This effect is large 5 (we return to the issue later in the paper) and well-defined. The black dummy variable has a coefficient in column 1 of Table $2 \mathrm{~A}$ of -0.7 , with a $\mathrm{E}$ statistic that exceeds twenty. There is a concave shape in age. In column 1 of Table $2 \mathrm{~A}$, over the relevant range, happiness grows with age. When other controls are introduced, however, it will be seen later in the paper that a minimum emerges around the middle of life. The monotonicity in Table 2A disappears when other independent variables -- especially work status and marriage -- are added.

Given the starkness of the conclusion that the USA has, in aggregate, apparently become more miserable over the last quarter of a century, it seems useful to examine sub-samples of the population. Later columns of Table $2 \mathrm{~A}$ do that. Columns 2 and 3 reveal that it is women rather than men who are experiencing the decline in well-being. This might be viewed as paradoxical: the last few decades are often seen as a period in the US in which discrimination against women has come down. Men report flat levels of well-being over this period (the time trend coefficient in column 2 of Table $2 \mathrm{~A}$ is positive but insignificantly different from zero). In both male and female columns, reported happiness rises as individuals get older. Moreover, the black coefficient is large and negative in both equations. It is possible to view this as evidence of discrimination against black people.

Columns 4 and 5 of Table $2 \mathrm{~A}$ separate the data by race. An interesting finding emerges. It can be seen, in column 5, that blacks are the only demographic group to be experiencing a statistically significant upward time trend in reported happiness. The concave shape in age disappears. The male dummy variable enters differently in columns 4 and 5; black men say they are happier than black women. Whites' happiness is trended strongly down over time -- in the sense that the time trend's

\footnotetext{
5 Although for convenience the paper's prose refers to coefficients, what is meant throughout the paper is 'marginals' in the usual ordered-logit sense.
} 
coefficient has a small standard error -- in column 4 of Table 2A. Therefore, over the period, the gap between the well-being of American whites and blacks has narrowed.

The last two columns of Table 2A look at age. Older people, in column 7, have a clear downward movement in well-being. In column 8 the young are slightly up, by contrast, although the trend is not well-defined.

Table 2B changes from sub-samples with only exogenous characteristics. It reports regression equations for other sub-groups of the population (looking at categories that are endogenous and thus, to a large degree, chosen by the individuals). In columns 8-10, the downward time trend is greatest for those who are out of the labor force. The consistently large black dummy in columns 8-14 is noteworthy.

Columns 11 and 12 divide the sample into Americans who have small and large amounts of education. Interestingly, the size of the downward time trend is approximately the same in the two subgroups. Conventional wisdom would not have predicted this; it is widely thought to have been a better era for the highly educated.

Columns 13-14 of Table 2B split the sample according to marital status - with the married as one category, while the other category combines the never married, those currently widowed or separated, and those divorced. In both columns, the time trend in happiness is positive. It is welldefined. This suggests that the statistical finding of a downward time trend in US happiness could be caused by a failure to distinguish between married and unmarried people. The decline of marriage in America -- from $67 \%$ of adults in the mid 70 s to $48 \%$ by the late 90 s -- may be one reason for the secular decline in happiness through the decades. But we show in the next section that this is probably not the full story. 
These US equations 6 treat each person's reported happiness level as ordinal in much the way that economic theory's use of indifference curves does. Tables $2 \mathrm{~A}$ and $2 \mathrm{~B}$ do not assume cardinal utility.

It is useful to check these patterns on another country. Although there are differences of detail, data from Great Britain give noticeably similar results. Here it is necessary to use a life-satisfaction question because there is no British happiness question over most of the required period. Questions about people's satisfaction with life seem of independent interest. Moreover, for the short run of years (1975-1986) over which both types of data are available, Appendix 2 confirms that the structures of happiness and life-satisfaction equations are similar.

The Eurobarometer Surveys provide cross-section information on approximately 55,000 Britons starting from the early 1970s (the annual sample is just over two thousand people). In each year they are asked:

On the whole, are you very satisfied, fairly satisfied, not very satisfied, or not at all satisfied with the life you lead? (Eurobarometer Survey Series).

The data come from the cumulative file and thirteen other surveys. In a way reminiscent of the US happiness results, the lower half of Table 1 illustrates that in the early 1970s approximately a third of British people say they are 'very satisfied' with life. The number is unchanged by the late 1990s. Appendix 3 shows the equivalent for Europe.

Table $3 \mathrm{~A}$ reports the same kinds of logit regression equations as for the US. Here life satisfaction is the dependent variable. It is not possible to include a dummy variable for race; but age,

\footnotetext{
6 These are, as explained, ordered logits. The usual approach in the psychology literature has been instead to assign numbers to happiness levels and then to use ordinary OLS regression methods. Strictly speaking, this is illegitimate (it cannot be assumed that "very happy" equals, say, twice "pretty happy"). Nevertheless, as shown in Appendix 1, we have found that the simple method gives similar results to those from ordered logits.
} 
age squared, gender, and a time trend, are again used as regressors. Column 1 of Table $3 \mathrm{~A}$ finds that well-being has not risen systematically in Great Britain from 1973 to 1998 . Although the coefficient on Time is positive, it is small and poorly defined (the t-statistic is 0.25 ). British males are less content than females. Age enters in a convex way: well-being is U-shaped in years.

Columns 2-5 of Table 3A break the data into different sub-samples (males, females, young, old). None of these groups has a statistically significant time-trend in well-being. Although poorly defined, the trends on males and females go in the opposite way from the United States. There is a well-defined U-shape in age in each of the five sub-samples separately. Regardless of age group, columns 4 and 5 of Table 3A show that men report lower well-being scores.

Table 3B examines further sub-samples for Great Britain. For those in work, column 6 reveals that there is a statistically significant upward time trend in life satisfaction. Its coefficient is 0.006 . There is no time trend among the out-of-the-labor-force group (the OLFs). Among the OLF individuals, men, who are disproportionately the retired, are more satisfied than women. The age and gender variables continue to enter as before. Columns 9 and 10 separate into those people with low and high levels of education (ALS is 'age left school'); both have time trends that are down, and approximately at the border of significance at the five per cent level.

An interesting finding in Table 3B is in columns 11-12. As was found for the United States, married people in Britain report secularly rising well-being over this quarter of a century. The coefficient is 0.0057 with a t-statistic of approximately four. Unmarried people, by contrast, have a flat time-trend. The proportion of the sample who are married changes from $72 \%$ in the early 1970 s to $55 \%$ by the late 1990s. 


\section{Happiness Equations with a Full Set of Controls}

The next step is to explore the patterns in well-being data by allowing for a larger set of controls, and especially for the effects of income and other economic variables. Table 4 begins this. Using again pooled US data from the beginning of the 1970s, it estimates ordered logit happiness equations in which are included a time trend, age and age squared, dummies for demographic and work characteristics, years of education, and dummies for marital status (including whether the individual's parents were divorced). Sample size is approximately 36,000 .

The first column of Table 4 continues to find a downward trend in American happiness. However, the coefficient on time is smaller than in Table 2, with a t-statistic of approximately 1.3. This suggests that it is changes in factors such as marital status and working life that explain part of the downward movement in reported levels of contentment. The null hypothesis of no change over time cannot be rejected in column 1 of Table 4 .

Looking across the columns, however, in this fuller specification it can be seen how different groups within the US economy have fared differently. Men's happiness has an upward trend in Table 4, column 2. Yet American women's well-being has fallen through the years. Blacks have trended up over time, with a large coefficient of 0.009 . Whites' well-being has been down. Income is at this juncture deliberately omitted from this table - to allow changing real incomes to be absorbed into the time variable.

One of the interesting conclusions, from the economist's point of view, is how influential nonfinancial variables appear to be in human welfare. The new variables, in the lower half of Table 4, enter powerfully. Work and marital status variables have large and well-defined effects. The single greatest depressant of reported happiness is the variable 'separated'; this is closely followed by 'widowed'. 
Being unemployed is apparently almost as bad, and also has a small standard error. According to the estimates, the joblessness effect is close in size to the unhappiness associated with divorce.

Marital break-up features in two other ways in Table 4. Second and subsequent marriages appear from these estimates to be less happy than first marriages. This confirms a result in the psychology literature (for example, Diener et al 1999). Moreover, a person whose parents were divorced (when the respondent was aged 16) has himself or herself a lower level of well-being in adulthood. It is not clear, of course, how much this kind of effect is truly causal. Genes rather than life events could be the explanation for such patterns in the data.

Years of education enter positively in a happiness equation. An economist might have guessed that this would occur -- because schooling would act as a proxy for earnings. A later table, however, reveals that it cannot be an earnings effect of this sort. Education is playing a role independently of income. The exact effect of age upon reported happiness is of interest. It is U-shaped, in Table 4, with a minimum in the late $30 \mathrm{~s}$.

Further checks, not reported, found that the addition of dummy variables for the number of children had coefficients that were small and insignificantly different from zero. State dummies were sometimes statistically significant but left the structure of the equations unchanged. Being religious entered positively but did not affect other coefficients.

When confronted with well-being data, it is natural for an economist to ask whether richer people report greater levels of well-being. The idea that income buys happiness is one of the assumptions -- made without evidence but rather for deductive reasons -- in microeconomics textbooks ${ }^{7}$. To explore this, the trend is dropped, and replaced with year dummies (to pick up, among other things, the nominal price level). Table 5 is the result for the US. Income per capita in the 
household enters positively with a tstatistic exceeding twelve. Interestingly, and perhaps surprisingly from an economist's point of view, the coefficients on the other variables in Table 5's well-being equations hardly alter. The amount of happiness bought by extra income is not as large as some would expect. To put this differently, the non-economic variables in happiness equations enter with large coefficients, relative to that on income.

Table 5, or its ordinary least squares equivalent (see Appendix 1), can be used to do a form of happiness calculus. The relative size of any two coefficients provides information about how one variable would have to change to maintain constant well-being in the face of an alteration in the other variable. To 'compensate' for a major life event such as being widowed or a marital separation, it would be necessary -- this calculation should be treated cautiously but it illustrates the size of the coefficients -- to provide an individual with approximately $\$ 100,000$ extra per annum ${ }^{8}$. Diener, Gohm, Suh and Oishi (undated) contains complementary evidence about the psychological benefits of marriage in different countries.

A different interpretation of this type of correlation is that happy people are more likely to stay married. It is clear that this hypothesis cannot easily be dismissed if only cross-section data are available. However, panel data on well-being suggest that similarly large effects are found when looking longitudinally at changes (thus differencing out person-specific fixed effects). See, for example, Winkelmann and Winkelmann (1998) and Clark (1999). There is also a separate literature in which it is concluded that marriage seems to provide protection against depression and mental ill-health (a recent paper, with references, is Cochrane, 1996).

\footnotetext{
7 An indirect utility function is of course increasing in income, and consumer theory can be done using revealed preference alone.

8 In 1990s dollars. For simplicity we have here used the ordinary least squares equation; similar numbers can be derived from ordered logits.
} 
If high income goes with more happiness, and characteristics such as unemployment and being black go with less happiness, it is reasonable to wonder whether a monetary value could be put on some of the other things that are associated with disutility. Further calculation suggests that to 'compensate' men exactly for unemployment would take a rise in income of approximately $\$ 60,000$ per annum, and to 'compensate' for being black would take $\$ 30,000$ extra per annum. These are large sums, and in a sense are a reflection of the low happiness value of extra income ${ }^{9}$.

British results are comparable. They are contained in Table 6. Here it is not possible to control as fully for income. However, the later columns of Table 6 incorporate an indicator of the family income quartile in which the individual falls.

Table 6 assumes that, apart from their income, a person's satisfaction with life depends upon a time trend, age and its square, gender, whether retired or keeping house or a student, work status, and marital status. A set of age-left-school dummies are also included to capture the individual's educational attainment. The time trend enters positively in column 1, with a coefficient of 0.0038 and t-statistic of 2.84. One interpretation of this is that well-being has been rising through the years in Great Britain contrary to the United States. However, that would be somewhat misleading, because what is being measured is a ceteris paribus effect. It needs to be compared to the zero coefficient on Time in Table 3A. The net effect of the variables listed in Table 6 is to remove the forces making for declining life satisfaction. In answering the question 'has Britain become more content?' it is therefore necessary to bear in mind the large rise in unemployment and fall in marriage.

The time trend for men in column 2 of Table 6 is larger than for women in column 3. Men appear to enjoy keeping house less than do women. Unemployment hits a male harder than it does a

9 It should be recalled that no trades are actually taking place, that budget constraints are not directly relevant in a simple sense, and that economists find these large partly because they are used to thinking, possibly incorrectly, of pecuniary factors as 
female. Women living as married are happier than those who are single, but markedly less than those who are legally married.

In Table 6, columns 4-6, it can be seen that the introduction of an independent variable for the person's income quartile affects other coefficients only a little. It continues to be true that joblessness hurts men more than women. The costs of unemployment are large relative to the costs from taking a cut in income. British men continue to be less contented than British women.

Table 7 sets out the British version of the United States equations of Table 4. The structure of the two is similar - despite the fact that the dependent variable is life satisfaction rather than happiness. Here a set of year-dummies controls for all macroeconomic changes in the British economy. The variables for income quartiles enter in a monotonic way: richer people are systematically more satisfied with their lives. In each of the three columns of Table 7, unemployment enters with a large negative coefficient. Men keeping house continue to be less satisfied with life.

The U-shape in age is again present in Tables 6 and 7. A notable feature is that the minimum is reached around the same age range for British men and women separately (39 in column 5 of Table 6 for men, and age 41 for women in column 6). Something systematic appears to be at work. No explanation is available even in the psychology literature. One tentative possibility is that this decline and then rise in well-being through the years may reflect a process of adaptation to circumstances; perhaps, by the middle of their lives, people relinquish some of their aspirations and thereby come to enjoy life more.

\section{Arguments and Counter-Arguments}

Equation 1 treats the subjectivity of responses as a component of the error term, but there still exist objections to the analysis.

providing most of life's well-being. 
First, it is not possible to control here for person-specific fixed effects, or, in other words, for people's dispositions. Nevertheless, the data are random cross-sections, and therefore suitable for the estimation of time trends. What small amount of regression work has been done on panels, moreover, finds similar microeconomic patterns to those documented here.

Second, individuals are not randomly assigned to events like divorce, so the calculation of, for example, the value of marriage describes an association in the data rather than clear cause-and-effect. This is an important problem. In the generic sense it is of course common throughout applied economics. The pragmatic response, here and elsewhere, is that at this point in the history of economic research it is necessary to document patterns and to be circumspect about causality. As explained earlier, marriage is believed by psychologists and psychiatrists to provide a protective effect to mental well-being (Argyle, 1989, contains further discussion of the evidence), but unambiguous proof would require a sharper statistical test than is possible with these data.

Third, people in the early 1970s may have used words differently from those in 1998 (so 'happy' no longer means exactly the same, perhaps). This is not immediately plausible; it would be more so over a century. Nevertheless, in so far as it holds, the paper's approach would be open to doubt, although the cross-section regression patterns would continue to be immune as long as yeardummies accurately captured the change-in-language effect as a set of intercept shifts.

Fourth, 'satisfaction' scores, as here for the British data set, may be inherently untrended perhaps because people unknowingly anchor their language on an observed aspiration level and adjust accordingly through the years. If true, this would create difficulties for some of the time-trend conclusions for Britain. But the cross-section findings would hold, and the US happiness results would go through. 
The analysis is not an attempt to define 'utility' in an exact empirical way. Nevertheless, the philosophy underlying the paper is that subjective well-being data may turn out to be useful to economists (as such statistics have to psychologists).

\section{Conclusions}

Reported levels of happiness are dropping through time in the United States. Life satisfaction is approximately flat in Great Britain. In a period of increasing material prosperity -- our data cover the period from the early 1970 s to the late 1990 s -- these results may surprise some observers.

Richard Easterlin (1974) argued that economic growth does not bring happiness to a society. Our data begin around the time of that article's publication, and our work provides some support, a quarter of a century later, for his views. Nevertheless, the picture is not a simple one. Some groups in society -- such as American men and blacks -- have become happier through the decades. Moreover, once the British equations control for enough personal characteristics (including whether unemployed or divorced), there is evidence of a statistically significant upward movement in well-being since the 1970s. This effect may be due to higher real income.

Other results emerge. In so far as conclusions can be drawn from random cross-section samples of people, they are the following.

1. Whatever the consequences of anti female-discrimination policy elsewhere in society, it has apparently not been successful in either country in creating rising well-being among women.

2. Black people in the US appear to be much less happy, ceteris paribus, than whites. One interpretation of this is that our methods provide a new way to document the existence of discrimination.

3. The difference in the well-being of racial groups in the United States has narrowed over the last few decades. Blacks have made up some ground, in other words. 
4. Our calculations suggest that to 'compensate' men for unemployment would take a rise in income at the mean of approximately $\$ 60,000$ per annum, and to 'compensate' for being black would take $\$ 30,000$ extra per annum. A lasting marriage is worth $\$ 100,000$ per annum when compared to being widowed or separated. Because there is no precedent for such calculations in the published social science literature, they should be treated cautiously.

5. Higher income is associated with higher happiness.

6. Reported well-being is greatest among women, married people, the highly educated, and those whose parents did not divorce. It is low among the unemployed. Second marriages are less happy.

7. Happiness and life satisfaction are U-shaped in age. In both Britain and the US, well-being reaches a minimum, other things held constant, around the age of forty. This regularity is not known to most social scientists. 
Figure 1

The function relating actual and reported well-being

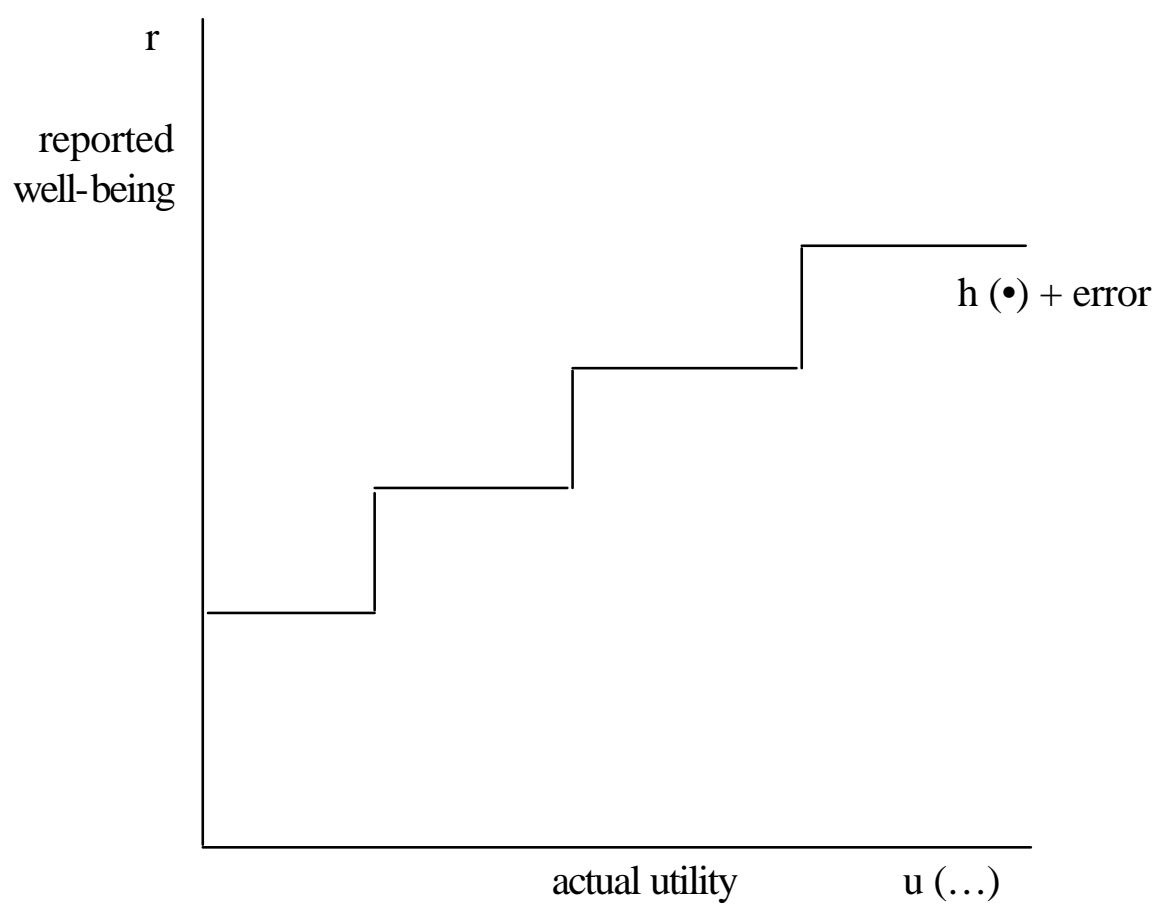




\section{Table 1. Happiness and Life Satisfaction: Averages for Different Periods}

a) The proportions of people giving different happiness answers in the United States 1972-98 $1972-1976 \quad 1977-1982 \quad 1983-1987 \quad 1988-1993 \quad 1994-1998$

$\begin{array}{llllrl}\text { All - not too happy } & 14 \% & 12 & 12 & 10 & 12 \\ \text { All - pretty happy } & 52 & 54 & 56 & 58 & 58 \\ \text { All - very happy } & 34 & 34 & 32 & 33 & 30 \\ & & & & & \\ \text { Male - not too happy } & 14 & 12 & 13 & 9 & 11 \\ \text { Male - pretty happy } & 54 & 56 & 57 & 58 & 58 \\ \text { Male - very happy } & 32 & 32 & 30 & 34 & 31 \\ & & & & & 13 \\ \text { Female - not too happy } & 13 & 12 & 12 & 57 & 59 \\ \text { Female - pretty happy } & 51 & 53 & 56 & 32 & 29 \\ \text { Female - very happy } & 36 & 35 & 33 & 9 & 11 \\ & & & & 57 & 59 \\ \text { White - not too happy } & 12 & 11 & 11 & 34 & 31 \\ \text { White - pretty happy } & 52 & 54 & 56 & & \\ \text { White - very happy } & 36 & 35 & 33 & 60 & 21 \\ & & & & 21 & \\ \text { Black - not too happy } & 26 & 23 & 58 & 21 & \end{array}$

b) The proportions of people giving different life-satisfaction answers in Great Britain 1973-98

$\begin{array}{lccccc} & 1972-1976 & 1977-1982 & 1983-1987 & 1988-1993 & 1994-1998 \\ \text { All - not at all } & 4 \% & 4 & 4 & 4 & 3 \\ \text { All - not very } & 11 & 10 & 10 & 10 & 10 \\ \text { All - fairly } & 54 & 54 & 55 & 55 & 57 \\ \text { All - very } & 31 & 32 & 31 & 31 & 31 \\ & & & & & \\ \text { Male - not at all } & 4 & 4 & 4 & 4 & 4 \\ \text { Male - not very } & 11 & 10 & 10 & 10 & 58 \\ \text { Male - fairly } & 55 & 55 & 57 & 57 & 29 \\ \text { Male - very } & 30 & 31 & 29 & 29 & 3 \\ & & & & & 9 \\ \text { Female - not at all } & 4 & 4 & 3 & 11 & 55 \\ \text { Female - not very } & 12 & 10 & 10 & 54 & 32 \\ \text { Female - fairly } & 53 & 53 & 54 & 32 & \end{array}$


Source: General Social Surveys - USA: Eurobarometers - Great Britain 
Table 2A. Happiness Equations for the United States, 1972-1998 (Ordered Logits).

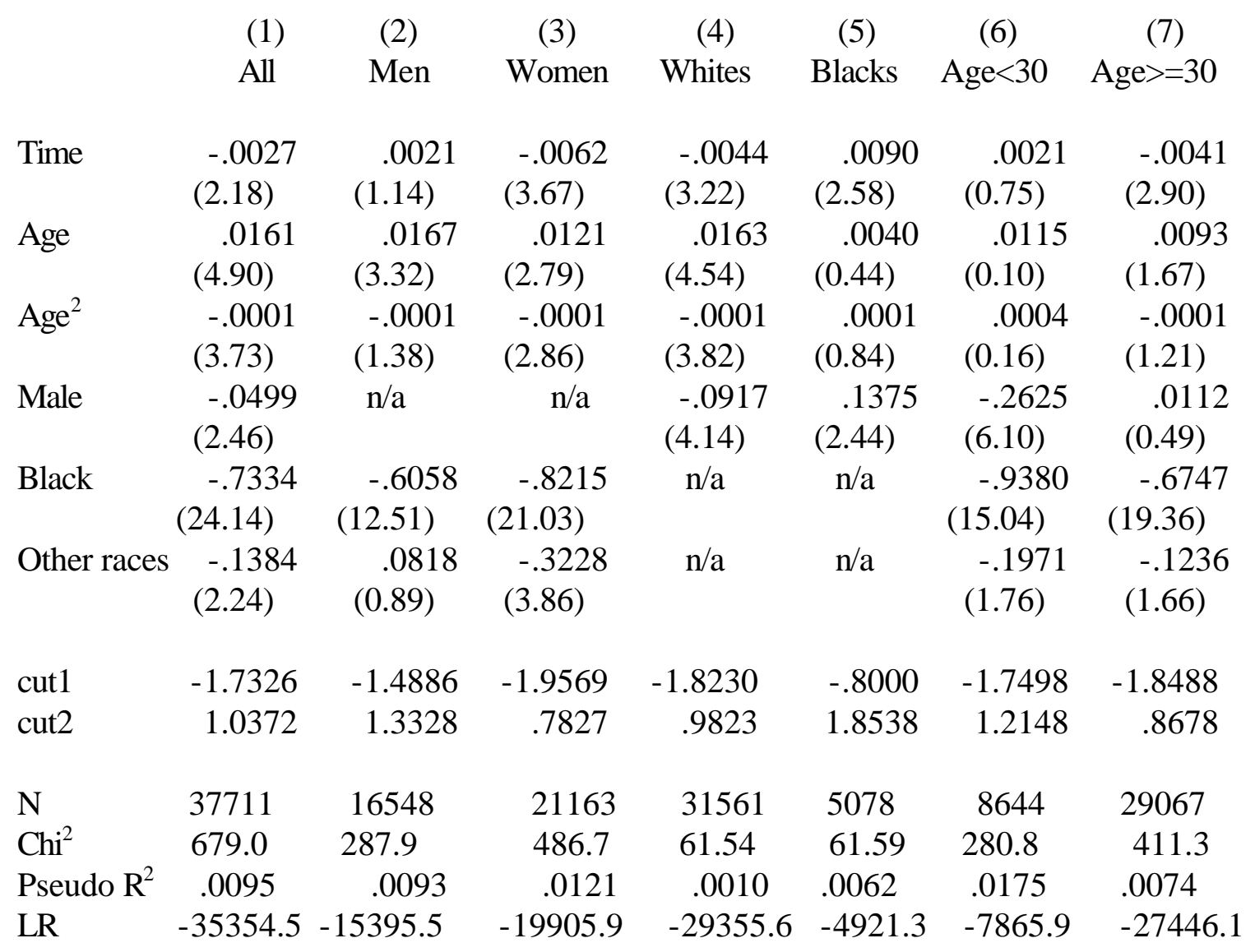

Source: General Social Survey, ORC

t-statistics are in parentheses 
Table 2B. Happiness Equations for the United States, 1972-1998 (Ordered Logits).

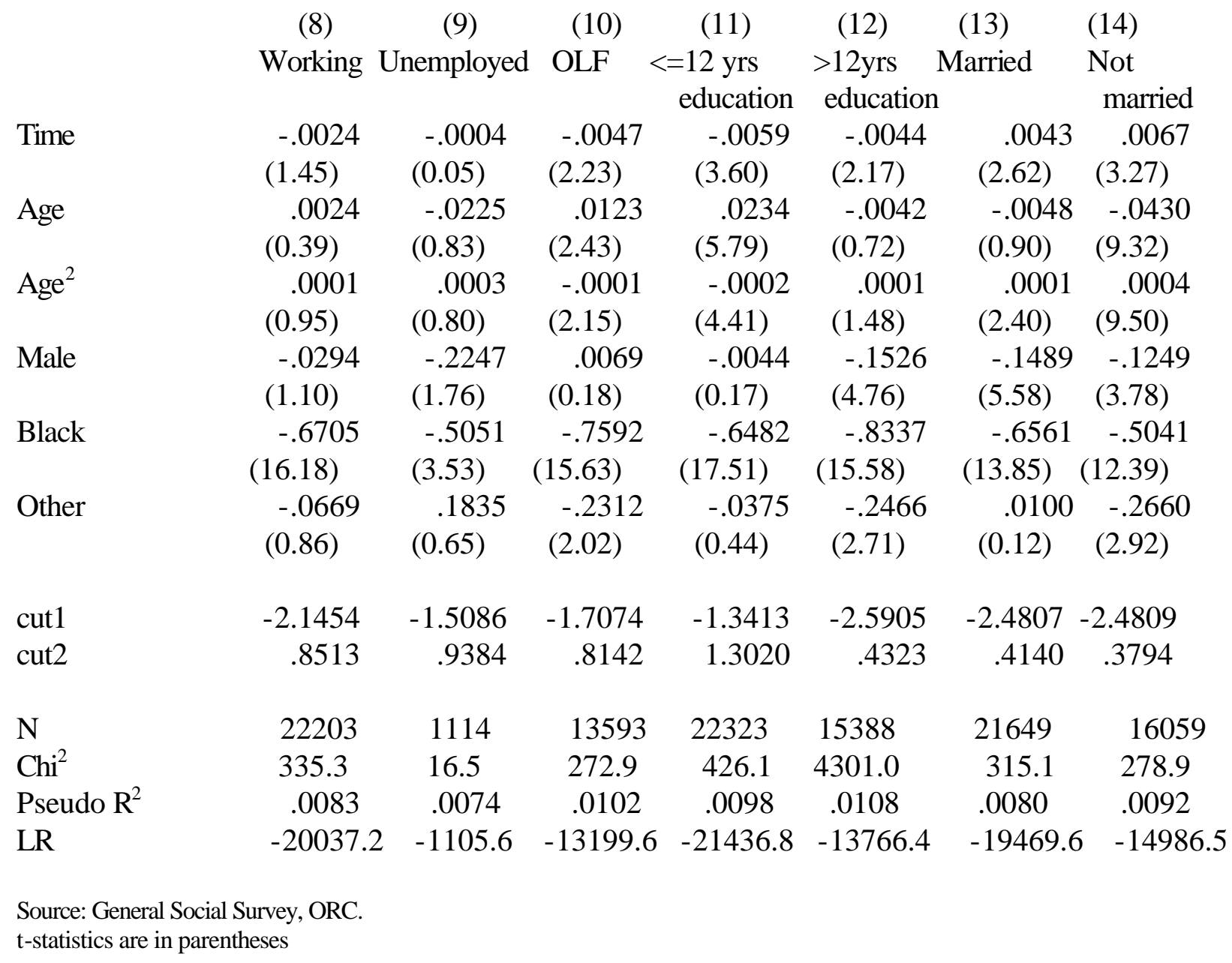


Table 3A. Life Satisfaction Equations for Great Britain, 1973-1998 (Ordered Logits).

Time

Age

$\mathrm{Age}^{2}$

Male

cut1

cut2

cut3

$\mathrm{N}$

$\mathrm{Chi}^{2}$

Pseudo $R^{2}$

LR
(1)

All

.0003

$(0.25)$

$-.0199$

(8.47)

.0003

(10.17)

$-.1159$

(7.13)

$-3.6440$

$-2.1886$

.4471

56863

222.9

.0019

$-59263.6$
(2)

Men

(3)

$-.0008$

(0.46)

$-.0296$

(8.56)

.0004

(10.66)

$\mathrm{n} / \mathrm{a}$
Women

.0012

(0.73)

$-.0133$

(4.14)

.0002

(4.50)

n/a
(4)

Age $<30$

$-.0041$

(1.85)

$-.2364$

(5.59)

.0048

(5.06)

$-.1878$

(5.95)

$-6.3655$

$-4.8372$

$-2.0475$

15546

29781

23.3

99.3

.0032

$-15635.0$
(5)

Age $>=30$

.0016

(1.17)

$-.0207$

(4.18) .0003

(5.59)

$-.0909$

(4.79)

$-3.6004$

$-2.1558$

.4129

41317

3165.7

.0019

$-43567.9$

t-statistics are in parentheses

Source: Eurobarometer Survey series

Eurobarometer and ICPSR Study Numbers and Titles

- $\quad$ Cumulative file 1973-1992 (\#9361)

34.1 Health Problems, Fall 1990 (\#9577)

37 Awareness of Maastricht and the Future of the EEC, March-April 1992 (\#9847)

37.1 Consumer Goods and Social Security, April-May, 1992 (\#9957)

38.1 Consumer Protection and Perceptions of Science and Technology, Nov 1992 (\#6045)

39 European Community Policies and Family Life, March-April 1993 (\#6195)

$40 \quad$ Poverty and Social Exclusion, October-November, 1993 (\#6360)

41 Trade Issues, Blood Donation, AIDS, and Smoking, March-June 1994 (\#6422)

42 The First Year of the New European Union, November-December 1994 (\#6518)

43.1 International Trade and Radiation Protection, April-May 1995 (\#6839)

44.2b BIS Mega Survey Policies \& Practices in Building EU Jan-March 1996 (\#6748)

44.3 Employment, Unemployment and Gender Equality, February-April 1996 (\#2443)

47.1 Images of Switzerland, Education Thru Life, \& Work Status, March-April 1997 (\#2089)

49 Food Product Safety, Child Sex Tourism, Health Care, \& Cancer, April-May 1998 (\#2559)

ICPSR Study Number in parentheses 
Table 3B. Life Satisfaction Equations for Great Britain, 1973-1998 (Ordered Logits).

\begin{tabular}{|c|c|c|c|c|c|c|c|}
\hline & (6) & (7) & (8) & (9) & (10) & (11) & (12) \\
\hline & Working & $\begin{array}{l}\text { Unemp- } \\
\text { loyed }\end{array}$ & OLF & $\begin{array}{l}\text { ALS } \\
<=16\end{array}$ & $\begin{array}{c}\text { ALS } \\
>16\end{array}$ & Married & $\begin{array}{l}\text { Not } \\
\text { married }\end{array}$ \\
\hline \multirow[t]{2}{*}{ Time } & .0060 & .0279 & . 0006 & -.0027 & -.0044 & . 0057 & .0006 \\
\hline & $(3.50)$ & $(5.21)$ & $(0.33)$ & (1.97) & (1.85) & (3.91) & $(0.28)$ \\
\hline \multirow[t]{2}{*}{ Age } & -.0237 & -.0826 & -.0201 & -.0148 & -.0068 & -.0308 & -.0762 \\
\hline & (5.14) & $(7.40)$ & (5.70) & (4.89) & $(1.29)$ & (7.37) & (21.33) \\
\hline \multirow{2}{*}{$\mathrm{Age}^{2}$} & .0003 & .0010 & .0002 & .0002 & .0002 & .0004 & .0008 \\
\hline & $(5.47)$ & (7.77) & $(6.28)$ & $(6.94)$ & (3.15) & $(9.09)$ & (21.23) \\
\hline Male & $\begin{array}{l}-.1220 \\
(5.18)\end{array}$ & $\begin{array}{l}-.4305 \\
(6.39)\end{array}$ & $\begin{array}{c}.0654 \\
(2.29)\end{array}$ & $\begin{array}{l}-.0729 \\
(3.64)\end{array}$ & $\begin{array}{l}-.2119 \\
(6.78)\end{array}$ & $\begin{array}{l}-.2025 \\
(9.69)\end{array}$ & $\begin{array}{l}-.0470 \\
(1.73)\end{array}$ \\
\hline cut1 & -4.0679 & -3.1998 & -3.5843 & -3.3333 & -3.7617 & -4.0484 & -4.4129 \\
\hline cut2 & -2.4787 & -1.8115 & -2.1487 & -1.9195 & -2.2136 & -2.5793 & -2.9563 \\
\hline cut3 & .4233 & .5268 & .3622 & .6539 & .5571 & .1294 & -.3146 \\
\hline $\mathrm{N}$ & 28929 & 3548 & 22367 & 37168 & 15645 & 35181 & 21354 \\
\hline $\mathrm{Chi}^{2}$ & 70.5 & 142.1 & 66.0 & 178.5 & 151.2 & 268.1 & 468.7 \\
\hline Pseudo $\mathrm{R}^{2}$ & .0012 & .0161 & .0014 & .0022 & .0048 & .0038 & .0102 \\
\hline LR & -28364.6 & -4336.2 & -23564.4 & -39649.2 & -15532.9 & $\begin{array}{ll}9 & -35516.7\end{array}$ & -22806.2 \\
\hline
\end{tabular}

Source: Eurobarometer survey series.

t-statistics are in parentheses

Notes: ALS= Age left school - individuals still in school at survey date excluded from columns 9 and 10. Columns 6-8 relate to 1975-1998 because labor force status is not defined consistently before 1975 . 
Table 4. Happiness Equations for the United States, 1972-1998 (Ordered Logits).

\begin{tabular}{|c|c|c|c|c|c|}
\hline & (1) & (2) & (3) & (4) & (5) \\
\hline & All & Men & Women & Blacks & Whites \\
\hline \multirow[t]{2}{*}{ Time } & -.0018 & .0045 & -.0069 & .0092 & -.0037 \\
\hline & (1.29) & (2.13) & (3.58) & $(2.27)$ & (2.44) \\
\hline \multirow[t]{2}{*}{ Age } & -.0220 & -.0218 & -.0223 & -.0188 & -.0252 \\
\hline & $(5.53)$ & $(3.42)$ & $(4.35)$ & $(1.70)$ & $(5.78)$ \\
\hline \multirow[t]{2}{*}{$\mathrm{Age}^{2}$} & .0003 & .0003 & .0003 & .0004 & 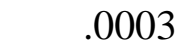 \\
\hline & (7.63) & (4.72) & (5.97) & (3.20) & (7.48) \\
\hline \multirow[t]{2}{*}{ Male } & -.1595 & $\mathrm{n} / \mathrm{a}$ & $\mathrm{n} / \mathrm{a}$ & .0662 & -.2142 \\
\hline & (6.78) & & & (1.03) & (8.29) \\
\hline \multirow[t]{2}{*}{ Black } & -.4494 & -.3336 & -.5135 & $\mathrm{n} / \mathrm{a}$ & $\mathrm{n} / \mathrm{a}$ \\
\hline & (13.88) & $(6.43)$ & $(12.33)$ & & \\
\hline \multirow[t]{2}{*}{ Other } & -.0680 & .1602 & -.2440 & $\mathrm{n} / \mathrm{a}$ & $\mathrm{n} / \mathrm{a}$ \\
\hline & (1.08) & (1.70) & (2.90) & & \\
\hline \multirow[t]{2}{*}{ Unemployed } & -.8321 & -.9713 & -.6124 & -.7923 & -.8748 \\
\hline & (12.94) & (12.40) & (5.30) & (5.67) & (11.68) \\
\hline \multirow[t]{2}{*}{ Retired } & -.0410 & -.0362 & -.0537 & -.2742 & -.0070 \\
\hline & $(0.93)$ & $(0.54)$ & $(0.87)$ & $(2.16)$ & $(0.15)$ \\
\hline \multirow[t]{2}{*}{ Student } & .1245 & .0893 & .1654 & -.2170 & .2015 \\
\hline & (1.92) & $(0.91)$ & (1.90) & (1.38) & (2.73) \\
\hline \multirow[t]{2}{*}{ Keeping home } & -.1045 & -.5165 & -.0803 & -.2059 & -.0905 \\
\hline & (3.26) & (3.14) & $(2.31)$ & $(2.52)$ & $(2.55)$ \\
\hline \multirow[t]{2}{*}{ Other } & -.6236 & -.7287 & -.5594 & -.7283 & -.6023 \\
\hline & $(6.98)$ & (5.74) & $(4.42)$ & (4.04) & (5.74) \\
\hline \multirow[t]{2}{*}{$>=2$ nd marriage } & -.1063 & -.0752 & -.1348 & -.1594 & -.0916 \\
\hline & (2.86) & (1.41) & (2.60) & (1.35) & (2.31) \\
\hline \multirow[t]{2}{*}{ Widowed } & -1.1109 & -1.3076 & -1.0305 & -.7139 & -1.1887 \\
\hline & (25.59) & (14.59) & (19.73) & $(6.42)$ & (24.71) \\
\hline \multirow[t]{2}{*}{ Divorced } & -.9874 & -.9927 & -.9757 & -.8076 & -1.0027 \\
\hline & (27.17) & $(16.82)$ & (21.04) & (8.37) & (24.98) \\
\hline \multirow[t]{2}{*}{ Separated } & -1.2523 & -1.2089 & -1.2513 & -.8870 & -1.4194 \\
\hline & (20.69) & (11.86) & $(16.60)$ & (8.48) & (18.25) \\
\hline \multirow[t]{2}{*}{ Never married } & -.7384 & -.7366 & -.7381 & -.5478 & -.7466 \\
\hline & (22.40) & $(15.44)$ & (15.93) & (6.38) & (20.30) \\
\hline \multirow[t]{2}{*}{ Parents divorced } & -.1957 & -.1250 & -.2400 & -.0554 & -.2267 \\
\hline & (5.79) & (2.38) & (5.43) & $(0.77)$ & (5.81) \\
\hline \multirow[t]{2}{*}{ Education } & .0482 & .0332 & .0646 & .0251 & .0570 \\
\hline & (13.03) & (6.44) & $(12.11)$ & $(2.45)$ & (13.91) \\
\hline cut1 & -2.4241 & -2.3900 & -2.2719 & -1.5238 & -2.5045 \\
\hline cut2 & .5112 & .6154 & .6196 & 1.2283 & .4862 \\
\hline $\mathrm{N}$ & 36012 & 15710 & 20302 & 4795 & 30153 \\
\hline $\mathrm{Chi}^{2}$ & 2960.7 & 1288.65 & 1748.9 & 276.0 & 2166.5 \\
\hline Pseudo $\mathrm{R}^{2}$ & .0435 & .0439 & .0453 & .0295 & .0387 \\
\hline
\end{tabular}


LR

Source: General Social Survey. t-statistics are in parentheses. Education is years of schooling 
Table 5. Happiness Equations for the United States, 1972-1998 (Ordered Logits) - Year Dummies Included.

\begin{tabular}{|c|c|c|c|c|c|}
\hline & (1) & (2) & (3) & (4) & (5) \\
\hline & All & Men & Women & Blacks & Whites \\
\hline \multirow[t]{2}{*}{ Age } & -.0339 & -.0325 & -.0348 & -.0211 & -.0389 \\
\hline & $(7.83)$ & $(4.80)$ & (6.17) & $(1.75)$ & $(8.24)$ \\
\hline \multirow[t]{2}{*}{$\operatorname{Age}^{2}$} & .0004 & .0004 & .0004 & .0004 & .0005 \\
\hline & $(9.30)$ & (5.67) & (7.30) & (2.96) & $(9.37)$ \\
\hline \multirow[t]{2}{*}{ Male } & -.1800 & $\mathrm{n} / \mathrm{a}$ & $\mathrm{n} / \mathrm{a}$ & .0238 & -.2311 \\
\hline & $(7.28)$ & & & $(0.34)$ & $(8.53)$ \\
\hline \multirow[t]{2}{*}{ Black } & -.4227 & -.3168 & -.4926 & $\mathrm{n} / \mathrm{a}$ & $\mathrm{n} / \mathrm{a}$ \\
\hline & $(12.14)$ & $(5.74)$ & $(10.92)$ & & \\
\hline \multirow[t]{2}{*}{ Other } & -.0383 & .1890 & -.2257 & $\mathrm{n} / \mathrm{a}$ & $\mathrm{n} / \mathrm{a}$ \\
\hline & $(0.57)$ & (1.92) & $(2.49)$ & & \\
\hline \multirow[t]{2}{*}{ Unemployed } & -.8029 & -.9143 & -.6097 & -.7718 & -.8334 \\
\hline & (11.83) & (11.13) & $(4.92)$ & (4.98) & $(10.67)$ \\
\hline \multirow[t]{2}{*}{ Retired } & .0075 & .0175 & -.0023 & -.2023 & .0378 \\
\hline & $(0.16)$ & $(0.25)$ & $(0.03)$ & $(1.46)$ & $(0.74)$ \\
\hline \multirow[t]{2}{*}{ Student } & .1759 & .1550 & .1988 & -.3113 & .2915 \\
\hline & $(2.53)$ & (1.50) & $(2.12)$ & (1.83) & $(3.71)$ \\
\hline \multirow[t]{2}{*}{ Keeping home } & -.0705 & -.3840 & -.0402 & -.1484 & -.0647 \\
\hline & (2.08) & $(2.23)$ & (1.09) & (1.68) & (1.73) \\
\hline \multirow[t]{2}{*}{ Other } & -.5496 & -.6036 & -.5269 & -.7223 & -.5249 \\
\hline & (5.67) & $(4.44)$ & (3.77) & $(3.58)$ & (4.66) \\
\hline \multirow[t]{2}{*}{$>=2$ nd marriage } & -.1194 & -.0954 & -.1467 & -.2078 & -.1043 \\
\hline & $(3.08)$ & (1.73) & $(2.68)$ & (1.68) & $(2.52)$ \\
\hline \multirow[t]{2}{*}{ Widowed } & -1.1465 & -1.3459 & -1.0536 & -.7088 & -1.2412 \\
\hline & $(24.50)$ & $(14.14)$ & (18.59) & $(5.93)$ & $(23.90)$ \\
\hline \multirow[t]{2}{*}{ Divorced } & -1.0141 & -1.0984 & -.9514 & -.8110 & -1.0401 \\
\hline & $(26.76)$ & $(17.60)$ & $(19.64)$ & $(7.90)$ & $(24.91)$ \\
\hline \multirow[t]{2}{*}{ Separated } & -1.2697 & -1.3478 & -1.1948 & -.8828 & -1.4504 \\
\hline & $(20.05)$ & $(12.61)$ & $(15.08)$ & $(7.96)$ & $(17.96)$ \\
\hline \multirow[t]{2}{*}{ Never married } & -.7830 & -.8192 & -.5269 & -.5805 & -.8028 \\
\hline & $(22.58)$ & $(16.33)$ & $(3.77)$ & (6.39) & $(20.77)$ \\
\hline \multirow[t]{2}{*}{ Parents divorced } & -.1932 & -.1368 & -.2300 & -.0682 & -.2255 \\
\hline & $(5.49)$ & $(2.52)$ & (4.97) & $(0.90)$ & $(5.57)$ \\
\hline \multirow[t]{2}{*}{ Education } & .0346 & .0203 & .0505 & .0142 & .0418 \\
\hline & $(8.41)$ & $(3.60)$ & $(8.38)$ & $(1.22)$ & $(9.22)$ \\
\hline \multirow{2}{*}{$\begin{array}{l}\text { Family income } \\
\text { (per capita)*10 }\end{array}$} & .0137 & .0140 & .0135 & .0126 & .0418 \\
\hline & $(12.22)$ & $(8.85)$ & $(8.20)$ & $(3.40)$ & $(9.22)$ \\
\hline cut1 & -2.8198 & -2.8034 & -2.6304 & -1.3746 & -3.0106 \\
\hline cut2 & .1494 & .2235 & .3048 & 1.4085 & .0188 \\
\hline
\end{tabular}




$\begin{array}{lccccc}\mathrm{N} & 32825 & 14608 & 18217 & 4271 & 27603 \\ \mathrm{Chi}^{2} & 2902.0 & 1304.4 & 1681.0 & 291.1 & 2188.0 \\ \text { Pseudo R } & .0470 & .0478 & .0487 & .0350 & .0428 \\ \text { LR } & -29450.8 & -12996.2 & -16409.6 & -4016.6 & -24452.2\end{array}$

Source: General Social Survey, ORC. t-statistics are in parentheses.

All equations include 19 year dummies 
Table 6. Life Satisfaction Equations for Great Britain, 1975-1998 (Ordered Logits).

(1) (2) (3) (4) (6) (6)

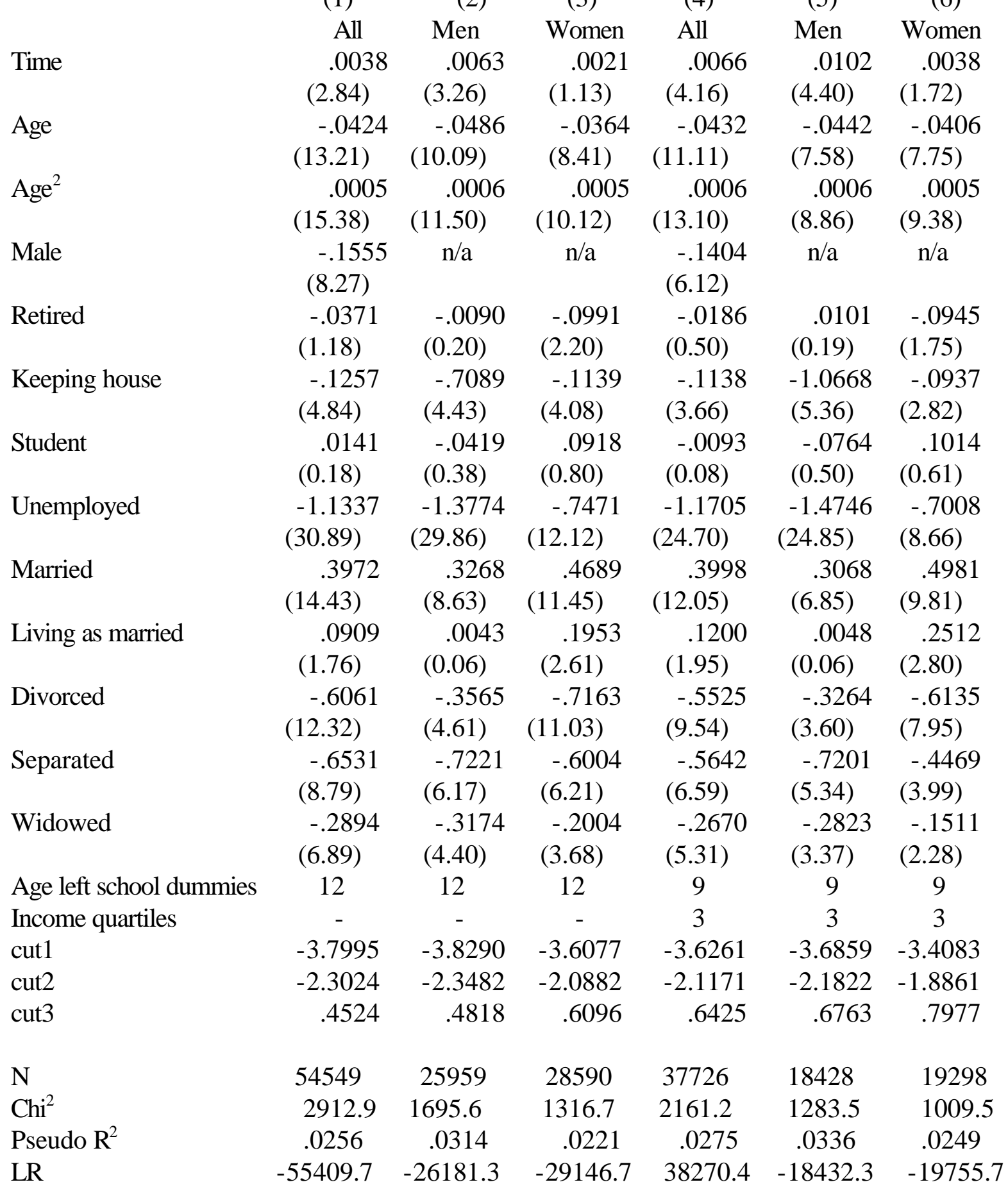

Source: Eurobarometer Survey series. t-statistics are in parentheses

Notes: Income quartiles have to be used because of the way in which the data are coded. Some sweeps have no income data, so the number of observations is lower than in earlier tables.

The number of age-left-school dummies equals 12 in columns 1-3, and equals 9 in columns 4-6. This is necessary because of the way in which Eurobarometer 43.1 - International Trade and Radiation Protection: April-May 1995 (\#6839) is coded. 
Table 7. Life Satisfaction Equations for Great Britain, 1975-1998 (Ordered Logits) - Year Dummies Included.

\begin{tabular}{|c|c|c|c|}
\hline & (1) & (2) & (3) \\
\hline & All & Men & Women \\
\hline \multirow[t]{2}{*}{ Age } & -.0424 & -.0433 & -.0402 \\
\hline & $(10.91)$ & $(7.41)$ & (7.66) \\
\hline \multirow[t]{2}{*}{$\mathrm{Age}^{2}$} & .0005 & .0006 & .0005 \\
\hline & (12.94) & $(8.72)$ & $(9.30)$ \\
\hline \multirow[t]{2}{*}{ Male } & -.1411 & $\mathrm{n} / \mathrm{a}$ & $\mathrm{n} / \mathrm{a}$ \\
\hline & $(6.14)$ & & \\
\hline \multirow[t]{2}{*}{ Retired } & -.0172 & .0103 & -.0934 \\
\hline & $(0.46)$ & $(0.19)$ & $(1.72)$ \\
\hline \multirow[t]{2}{*}{ Keeping house } & -.1184 & -1.0712 & -.0970 \\
\hline & $(3.80)$ & $(5.36)$ & $(2.91)$ \\
\hline \multirow[t]{2}{*}{ Student } & -.0175 & -.0879 & .0870 \\
\hline & $(0.16)$ & $(0.57)$ & $(0.52)$ \\
\hline \multirow{2}{*}{ Unemployed } & -1.1798 & -1.4878 & -.7196 \\
\hline & $(24.83)$ & $(24.91)$ & $(8.86)$ \\
\hline \multirow[t]{2}{*}{ Married } & .3996 & .3053 & .4984 \\
\hline & $(12.04)$ & $(6.81)$ & $(9.81)$ \\
\hline \multirow[t]{2}{*}{ Living as married } & .1155 & .0001 & .2464 \\
\hline & $(1.88)$ & $(0.00)$ & $(2.74)$ \\
\hline \multirow{2}{*}{ Divorced } & -.5586 & -.3387 & -.6171 \\
\hline & (9.64) & (3.73) & $(8.00)$ \\
\hline \multirow[t]{2}{*}{ Separated } & -.5704 & -.7177 & -.4604 \\
\hline & $(6.66)$ & $(5.33)$ & $(4.11)$ \\
\hline \multirow[t]{2}{*}{ Widowed } & -.2675 & -.2895 & -.1500 \\
\hline & $(5.32)$ & $(3.45)$ & $(2.26)$ \\
\hline \multirow[t]{2}{*}{$2^{\text {nd }}$ Income quartile } & .0989 & .0564 & .1113 \\
\hline & $(3.24)$ & $(1.26)$ & $(2.65)$ \\
\hline \multirow[t]{2}{*}{$3^{\text {rd }}$ Income quartile } & .1563 & .0673 & .2112 \\
\hline & $(5.08)$ & $(1.50)$ & $(4.94)$ \\
\hline \multirow[t]{2}{*}{$4^{\text {th }}$ Income quartile } & .3219 & .3096 & .3199 \\
\hline & $(10.67)$ & $(6.93)$ & $(7.72)$ \\
\hline Age-left-school dummies & 9 & 9 & 9 \\
\hline Year dummies & 21 & 21 & 21 \\
\hline cut1 & -3.5679 & -3.6124 & -3.3660 \\
\hline cut2 & -2.0570 & -2.1071 & -1.8414 \\
\hline cut3 & .7085 & .7585 & .8489 \\
\hline $\mathrm{N}$ & 37726 & 18428 & 19298 \\
\hline $\mathrm{Chi}^{2}$ & 2261.8 & 1339.7 & 1067.1 \\
\hline $\mathrm{R}^{2}$ & .0287 & .0351 & .0263 \\
\hline LR & -38220.1 & -18404.2 & -19726.9 \\
\hline
\end{tabular}


Source: Eurobarometer Survey series. Income quartiles have to be used because of the way in which the data are coded. $\mathrm{t}$ statistics are in parentheses. 


\section{Appendix 1}

\section{The OLS form}

If a simple OLS happiness regression is estimated, using the US General Social Survey, it produces the following equation. The means are as stated. The dependent variable is constructed by assigning 3 to very happy, 2 to pretty happy, and 1 to not too happy. There is then an implicit assumption of cardinality.

The coefficients on the independent variables include (with t statistics in parentheses):

$\begin{array}{lc}\text { Age } & -.0103(7.90) \\ \text { Age squared } & .0001(9.33) \\ \text { Male } & -.0537(7.11) \\ \text { Time } & -.0027(5.53) \\ \text { Black } & -.1286(12.47) \\ \text { Other } & -.0147((0.73) \\ \text { Second marriage } & .0403(3.43) \\ \text { Widowed } & -.3060(18.07) \\ \text { Divorced } & -.2702(18.38) \\ \text { Separated } & -.3439(16.40) \\ \text { Never married } & -.1984(13.78) \\ \text { Per capita income } & .00000409(12.06) \\ \text { Unemployed } & -.2444(12.13) \\ \text { Retired } & -.0019(0.13) \\ \text { Keeping house } & -.0234(2.26) \\ \text { Student } & .0499(2.38) \\ \text { Other work status } & -.1684(5.85) \\ & \\ \text { R } & .0845 \\ \text { F }(19,32805) & 159.4 \\ \text { Root MSE } & .6038\end{array}$

The omitted base case is married, white, female, employed.

Total number of observations $=$ 32825

Mean of the dependent happiness variable $=\quad 2.2$

Mean of the income variable in dollars $=\quad 11236$

Income in $1973=\quad 4261$

Income in $1983=$

Income in $1998=\quad 20457$ 


\section{Appendix 2}

\section{Comparing Happiness and Life Satisfaction Equations where Data on Both are Available}

GB Eurobarometers, 1975-1986

$$
\text { Happiness L Life satisfaction }
$$

\begin{tabular}{|c|c|c|}
\hline Age & $-.0456(6.93)$ & -.0314 (4.83) \\
\hline $\mathrm{Age}^{2}$ & $.0005(7.51)$ & $.0004 \quad(6.20)$ \\
\hline Male & $-.1921(4.89)$ & $-.1494 \quad(3.85)$ \\
\hline ALS 15 & $.1161(2.12)$ & .1389 (2.56) \\
\hline ALS 16 & .2449 (4.19) & $.2390 \quad(4.15)$ \\
\hline ALS 17 & $.1941(2.58)$ & $.2708 \quad(3.65)$ \\
\hline ALS 18 & $.3145(3.78)$ & .2868 (3.47) \\
\hline ALS 19 & $.3944(2.78)$ & .5313 (3.82) \\
\hline ALS 20 & .0131 (0.08) & .4512 (2.78) \\
\hline ALS 21 & $.3350(3.12)$ & $.5964 \quad(5.68)$ \\
\hline ALS $>=22$ & .1789 (1.97) & $.5561 \quad(6.21)$ \\
\hline Still studying & $.1949(1.22)$ & .2687 (1.69) \\
\hline Married & .4121 (7.14) & $.1262(2.20)$ \\
\hline Living together & $-.1136(0.76)$ & $-.1562(1.06)$ \\
\hline Divorced & $-.4553(4.02)$ & $-.7834 \quad(7.00)$ \\
\hline Separated & $-.5247(3.15)$ & $-.6663(4.03)$ \\
\hline Widowed & $-.4326(5.09)$ & $-.6305 \quad(7.41)$ \\
\hline Retired & $-.0071(0.10)$ & $.1232(1.80)$ \\
\hline Housewife & $-.1421(2.87)$ & $\begin{array}{ll}-.0409 & (0.83)\end{array}$ \\
\hline Student & -.0929 (0.66) & $\begin{array}{ll}-.0701 & (0.50)\end{array}$ \\
\hline Unemployed & $-.9868(11.67)$ & $-1.4061(16.73)$ \\
\hline cut1 & -2.3649 & -3.7574 \\
\hline cut2 & .4567 & -2.2476 \\
\hline cut3 & & .5135 \\
\hline $\mathrm{N}$ & 14114 & 14114 \\
\hline $\mathrm{Chi}^{2}$ & 508.66 & 681.7 \\
\hline Pseudo $\mathrm{R}^{2}$ & .0189 & .0232 \\
\hline Log likelihood & -13201.3 & -14334.6 \\
\hline
\end{tabular}

Source: Eurobarometer Cumulative File (ICPSR \#9361).

$\mathrm{t}$-statistics in parentheses 


\section{Appendix 3}

\section{Life-Satisfaction Means for Europe}

The level of life satisfaction in Europe as a whole also appears to have been roughly constant over time. According to the Eurobarometer surveys, the means (weighted by their relative sizes) to the life satisfaction question referred to in the paper for the first 12 members of the EU (France, Belgium, Netherlands, West Germany, Italy, Luxembourg, Denmark, Ireland, UK, Greece, Spain, Portugal) were as follows:

$1973 \quad 1983$

Not at all satisfied $\quad 4 \% \quad 6 \quad 5$

$\begin{array}{llll}\text { Not very satisfied } & 16 & 16 & 17\end{array}$

$\begin{array}{lll}\text { Fairly satisfied } & 58 & 59\end{array}$

$\begin{array}{llll}\text { Very satisfied } & 22 & 19 & 19\end{array}$

Source: Eurobarometers cumulative file (ICPSR \# 9361) for 1973 and 1983 and Eurobarometer \#47.1 (ICPSR \#2089) for April 1997. 


\section{$\underline{\text { References }}$}

Andrews, F.M. (1991). "Stability and Change in Levels and Structure of Subjective Well-Being: USA 1972 and 1988", Social Indicators Research, 25, 1-30.

Argyle, M. (1989). The Psychology of Happiness, Routledge, London.

Blanchflower, D.G. and Freeman, R.B. (1997). "The Legacy of Communist Labor Relations", Industrial and Labor Relations Review, 50, 438-459.

Blanchflower, D.G. and Oswald, A.J. (1998). “What Makes an Entrepreneur?”, Journal of Labor Economics, 16, 26-60.

Blanchflower, D.G. and Oswald, A.J. (1999). "The Rising Well-Being of the Young", forthcoming in Youth Employment and Joblessness in Advanced Countries, edited by D.G. Blanchflower and R.B. Freeman, University of Chicago Press and NBER.

Blanchflower, D.G., Oswald, A.J. and Warr, P.B. (1993). "Well-Being Over Time in Britain and the USA", conference paper, LSE.

Campbell, A. (1981). The Sense of Well-Being in America, McGraw Hill, New York.

Chen, P.Y. and Spector, P.E. (1991). "Negative Affectivity as the Underlying Cause of Correlations Between Stressors and Strains", Journal of Applied Psychology, 7, 398-407.

Clark, A.E. (1996). "Job Satisfaction in Britain", British Journal of Industrial Relations, 34, 189-217.

Clark, A.E. (1999). "Well-Being in Panels", mimeo, University of Orleans.

Clark, A.E. and Oswald, A.J. (1994). "Unhappiness and Unemployment”, Economic Journal, 104, 648-659.

Cochrane, R. (1996), "Marriage and Madness", Psychology Review, 3, 2-5.

Cooper, B. and Garcia-Penalosa, C. (1999). "Status Effects and Negative Utility Growth", mimeo, Nuffield College, Oxford.

Diener, E. (1984). “Subjective Well-Being”, Psychological Bulletin, 95, 542-575.

Diener, E., Gohm, C.L., Suh, E. and Oishi, S. (undated), "Similarity of the Relations Between Marital Status and Subjective Well-Being Across Cultures", mimeo, Psychology Department, University of Illinois, Urbana.

Diener, E., Suh, E.M., Lucas, R.E., and Smith, H.L. (1999). "Subjective Well-Being: Three Decades of Progress", Psychological Bulletin, 125, 276-303. 
Di Tella, R., MacCulloch, R. and Oswald, A.J. (1998), “The Macroeconomics of Happiness”, mimeo, Harvard Business School.

Douthitt, R.A., MacDonald, M. and Mullis, R. (1992). "The Relationship Between Measures of Subjective and Economic Well-Being: A New Look", Social Indicators Research, 26, 407-422.

Easterlin, R.A. (1974). "Does Economic Growth Improve the Human Lot? Some Empirical Evidence", in Nations and Households in Economic Growth: Essays in Honour of Moses Abramowitz, edited by P.A. David and M.W.Reder, Academic Press, New York and London.

Easterlin, R.A. (1995). "Will Raising the Incomes of All Increase the Happiness of All?", Journal of Economic Behavior and Organization, 27, 35-47.

Fordyce, M.W. (1985). "The Psychap Inventory: A Multi-Scale Test to Measure Happiness and its Concomitants", Social Indicators Research, 18, 1-33.

Fox, C.R. and Kahneman, D. (1992). "Correlations, Causes and Heuristics in Surveys of Life Satisfaction”, Social Indicators Research, 27, 221-234.

Frank, R. H. (1985). Choosing the Right Pond, Oxford University Press, New York.

Frank, R.H. (1997). “The Frame of Reference as a Public Good”, Economic Journal, 107, 18321847.

Frank, R.H. (1999). Luxury Fever, Oxford University Press, Oxford.

Frey, B.S. and Schneider, F. (1978). "An Empirical Study of Politico-Economic Interaction in the United States", Review of Economics and Statistics, 60(2), 174-183.

Frey, B.S. and Stutzer, A. (1998). "Measuring Preferences by Subjective Well-Being", mimeo, University of Zurich.

Frey, B.S. and Stutzer, A. (1999). "Happiness and Economics”, mimeo, University of Zurich.

Frisch, M.B, Cornell, J., Villanueva, M., and Retzlaff, P.J. (1992). "Clinical Validation of the Quality of Life Inventory: A Measure of Life Satisfaction for Use in Treatment Planning and Outcome Assessment", Pyschological Assessment, 4, 92-101.

Gallie, D., White, M., Cheng, Y. and Tomlinson, M. (1998). Restructuring the Employment Relationship, Oxford University Press, Oxford.

Hirsch, F. (1976). The Social Limits to Growth, Harvard University Press, Cambridge, Mass. 
Inglehart, R. (1990). Culture Shift in Advanced Industrial Society, Princeton University Press, Princeton.

Kahneman, D., Wakker, Peter P. and Sarin, Rakesh (1997). "Back to Bentham? Explorations of Experienced Utility", Quarterly Journal of Economics, 112, 375-406.

Keely, L.C. (1999). "Why Isn’t Growth Making Us Happier?", mimeo, New College, Oxford University.

Konow, J. and Earley, J. (1999) "The Hedonistic Paradox: Is Homo-Economicus Happier?", mimeo, Loyola Marymount University, Dept of Psychology.

Larsen, R.J., Diener, E., and Emmons, R.A. (1984). "An Evaluation of Subjective Well-Being Measures", Social Indicators Research, 17,1-18.

Layard, R. (1980). “Human Satisfactions and Public Policy”, Economic Journal, 90, 737-750.

MacCulloch, R. (1996). "The Structure of the Welfare State”, doctoral thesis, Oxford University.

Mullis, R.J. (1992). "Measures of Economic Well-Being as Predictors of Psychological Well-Being", Social Indicators Research, 26, 119-135.

Myers, D.G. (1993). The Pursuit of Happiness, Aquarian, London.

Ng, Y.K. (1996). "Happiness Surveys: Some Comparability Issues and an Exploratory Survey Based on Just Perceivable Increments", Social Indicators Research, 38, 1-27.

Ng, Y.K. (1997). "A Case for Happiness, Cardinalism, and Interpersonal Comparability", Economic Journal, 107, 1848-1858.

Offer, A. (1998). "Epidemics of Abundance: Overeating and Slimming in the USA and Britain since the 1950s", University of Oxford Discussion Papers in Economic and Social History, 25.

Oswald, A.J. (1997). "Happiness and Economic Performance”, Economic Journal, 107, 1815-1831.

Pavot, W. and Diener, E. (1993). "Review of the Satisfaction with Life Scales", Psychological Assessment, 5, 164-172.

Schor, J. (1998). The Overspent American, Basic Books, New York.

Scitovsky, T. (1976). The Joyless Economy, Oxford University Press, Oxford.

Shin, D.C. (1980). "Does Rapid Economic Growth Improve the Human Lot? Some Empirical Evidence", Social Indicators Research, 8, 199-221. 
Veenhoven, R. (1991). “Is Happiness Relative?", Social Indicators Research, 24, 1-34.

Veenhoven, R. (1993). Happiness in Nations: Subjective Appreciation of Life in 56 Nations, 19461992, Erasmus University Press, Rotterdam.

Warr, P.B. (1980). "The Springs of Action" in A.J. Chapman and D.M. Jones (Eds.), Models of Man (pp.161-181). Leicester: British Psychological Society.

Warr, P.B. (1990). "The Measurement of Well-Being and Other Aspects of Mental Health", Journal of Occupational Psychology, 63, 193-210.

Watson, D. and Clark, L.A. (1991). "Self Versus Peer Ratings of Specific Emotional Traits: Evidence of Convergent and Discriminant Validity", Journal of Personality and Social Psychology, 60, 927-940.

Winkelmann, L. and Winkelmann, R. (1998). "Why are the Unemployed so Unhappy?", Economica, 65(257), 1-15. 